\title{
Site of Resection or Biopsy
}

National Cancer Institute

\section{Source}

National Cancer Institute. Site of Resection or Biopsy. NCI Thesaurus. Code C156421.

The anatomic site from which a biopsy sample, or other tissue, was removed. 